\title{
MORPHOLOGICAL AND MOLECULAR CHARACTERIZATION OF SPECIES OF TULASNELLA (HOMOBASIDIOMYCETES) ASSOCIATED WITH NEOTROPICAL PLANTS OF LAELIINAE (ORCHIDACEAE) OCCURING IN BRAZIL
}

\author{
Paulo Ricardo M. AlmeidA ${ }^{1,4}$, Cassio van den Berg ${ }^{2}$ \& Aristoteles Goes-Neto 3 \\ 'Programa de Pós - Graduação em Botânica, Departamento de Ciências Biológicas, Universidade Estadual de \\ Feira de Santana (UEFS), Rodovia Br 116, Km 03, Feira de Santana - Bahia - Brazil. CEP: 44031-460 \\ ${ }^{2}$ Laboratório de Sistemática Molecular de Plantas, Departamento de Ciências Biológicas, Módulo 1, Edifício \\ LABIO, Universidade Estadual de Feira de Santana, Rodovia Br 116, Km 03, Feira de Santana - Bahia - \\ Brazil. CEP: 44031-460 \\ ${ }^{3}$ Laboratório de Pesquisa em Microbiologia, Departamento de Ciências Biológicas, Módulo 1, Edifício \\ LABIO, Universidade Estadual de Feira de Santana, Rodovia Br 116, Km 03, Feira de Santana - Bahia - \\ Brazil. CEP: 44031-460
}

4Author for correspondence: pauloricardoma@yahoo.com.br

KeY WORDS:Laeliinae, Tulasnella, orchid mycorrhiza, conservation

\section{Introduction}

Tullasnella spp. have been found forming mycorhizal associations with plants of all Orchidaceae subfamilies, and they are one of the main symbionts in partially micoheterotrophic plants (Taylor et al. 2002). Little is known about mycorhizal fungi of Neotropical Orchidaceae, especially in Laeliinae that occur in distinct environments such as "Restingas", Seasonal Forests and "Campos Rupestres" (Cruz et al. 2003, Britto et al. 1993, França et al. 1997, Withner 2000).

Some few studies in completely mycoheterotrophic Epidendroideae have been shown that these plants form mycorrhizal associations mainly with fungi of the genera Russula, Thelephora, Sebacina, as well as other ectomycorrhizal Basidiomycetes in trees (Taylor and Bruns, 1999, 1997, Taylor et al. 2003, Selosse et al. 2002, Girlanda et al. 2006). There are other studies indicating a preferential association between basidiomycetous fungi and Orchidaceae plants as in Oncidiinae with Ceratobasidium and Cypripedium with Tulasnella (Otero et al. 2002, 2004, Shefferson et al. 2005). These works suggest a putative specificity and recruiting of these plants in the environment where they occur.

Laeliinae plants have been intensively and indiscriminately collected in Brazil, leading to a significant reduc- tion in their natural populations. In order to establish conservation strategies to these threatened plants as there is an indication in literature showing a preferential association between some specific fungi and Orchidaceae, the identity of symbiont fungi forming mycorrhizal associations in Brazilian Laeliineae was studied, aiming to an efficient in situ and ex situ conservation.

\section{Methodology}

\section{COLLECTION SITES AND ISOLATION OF FUNGI}

Orchidaceae plants were collected from natural populations that occur in two distinct Brazilian States. A total of 20 natural populations, including plants of Laeliinae and Pleurothallidinae were sampled. From each population, one or two individual plants were collected and their roots were sampled in a period of one to two weeks since collection date. The individuals were selected from distinct environments (Tropical Rain Forest, "Restinga", and "Campo Rupestre") and the isolation of associated fungi was carried out according to Warcup and Talbot (1967).

\section{Morphological CHARACTERIZATION OF FUnGaL} COLONIES

Fungal colonies were incubated for 30 days in PDA (potato-dextrose agar) and OA (3\% oat meal agar) to induce the formation of monilioid cells, and they 
were further analysed to determine the form, number and array of the cells. Macroscopic and microscopic somatic features of the colonies were also described. In order to analyse the nuclear condition, hyphal nuclei were stained according to Sneh et al. (1991).

\section{MOLECULAR CHARACTERIZATION OF FUNGAL ISOLATES}

All the isolates were first cultivated in BDA for 15 days at $28{ }^{\circ} \mathrm{C}$, including an Epulorhiza epiphytica Pereira, Rollemberg et Kasuya isolate, gently sent by Mycorrhizal Association Lab of the Federal University of Viçosa, Brazil. DNA extraction was carried out according to CTAB protocol (Doyle \& Doyle, 1987). Double-stranded symmetric PCR reactions were carried out in $0.2-\mathrm{mL}$ tubes in $50 \mu \mathrm{L}$ reaction volume, using the primers ITS5 and ITS4 that amplify the Internal Transcribed Spacer (ITS region) of nuclear ribosomal DNA (White et al., 1990). PCR products were purified using EXOSAP and were sequenced in an automatic DNA sequencer (SCE 2410, Spectrumedix LLC). Chromatograms were edited using GAP4 software in Staden (Staden, 1996). Resulting sequences were submitted to a similarity search using BLASTn software of NCBI and aligned with Clustal X (Thompson et al. 1997). Phylogenetic parsimony analyses (heuristic search, TBR algorithm) were conducted in PAUP 4.0 (Swofford, 1998). Clade robustness was assessed using bootstrap proportions (1000 replications) (Felsenstein, 1985).

\section{Results and discussion}

\section{IDENTIFICATION OF ISOLATES FROM LAELIINAE}

According to morphological characterization, the isolates belong to the genus Tulasnella (Basidiomycetes) (Rasmussen 1995, Currah and Zelmer 1992, Currah et al. 1997b), but the somatic characters were not stable enough to differentiate the groups. All the colonies presented an entire submersed margin and binucleate hyphae (Fig.1). In all the isolates monilioid cells showed a very high morphological plasticity with cell chains ranging from 3 to 15 cells with or without ramification. Andersen (1990) pointed out that somatic features were not reliable, since there is not even one character that could be taken as a parameter in intraspecific level. The three isolates showed a growing pattern typical of rhizoctonoid fungi, but they did not produce monilioid cells even when they were submitted to distinct culture media.

All the sequences were compared to NCBI database, revealing that the isolates belonged to different lineages of Tulasnella including $T$. violea and $T$. calospora. Some sequences were considerably difficult to align and they were initially excluded from the phylogeny. In the phylogenetic tree (Fig. 2) some of the isolates represented lineages of Tulasnella calospora and others were lineages of Epulorhiza epiphytica, both of them significantly supported by bootstrap analysis. E. epiphytica is the only species described for Brazil and it was isolated from host plants that naturally occur in the State of Minas Gerais (Pereira et al. 2003). These results suggest that all the isolates are distinct lineages of Tulasnella, and that this possibly reflects the different environments where host plants occur.

\section{Relationships between Laelinae and Tulasnelaceae}

In accordance to the results, although host plants live in completely different environments where the research availability is distinct, one can observe the strong trend of studied plants to form mycorrhizal associations with fungi of the genus Tulasnella (Almeida 2006). Studies on Australian orchids revealed that Diurideae plants has a strict specificity relationship with the fungi Sebacina vermifera and some lineages of Tulasnella, including Tulasnella calospora, which has been considered as a universal species (Rasmussen, 1995, Warcup, 1981, 1988, 1971). Inside Diurideae, all the studied species that belong to Drakaeinae and Diuridinae associate to Tulasnella, and all the studied species (except for those from genera Lyperanthus and Bumettia) that belong to Caladeniinae present a strict relationship with Sebacina (Warcup, 1981, Dressler, 1993). As all the isolates were obtained from pelotons, they are mycorrizal fungi.

Despite of the great advances obtained with the direct identification of fungi by molecular techniques such as PCR and sequencing, the morphological study of the isolates is still very important, mainly for the establishing of true biological entities or species. 

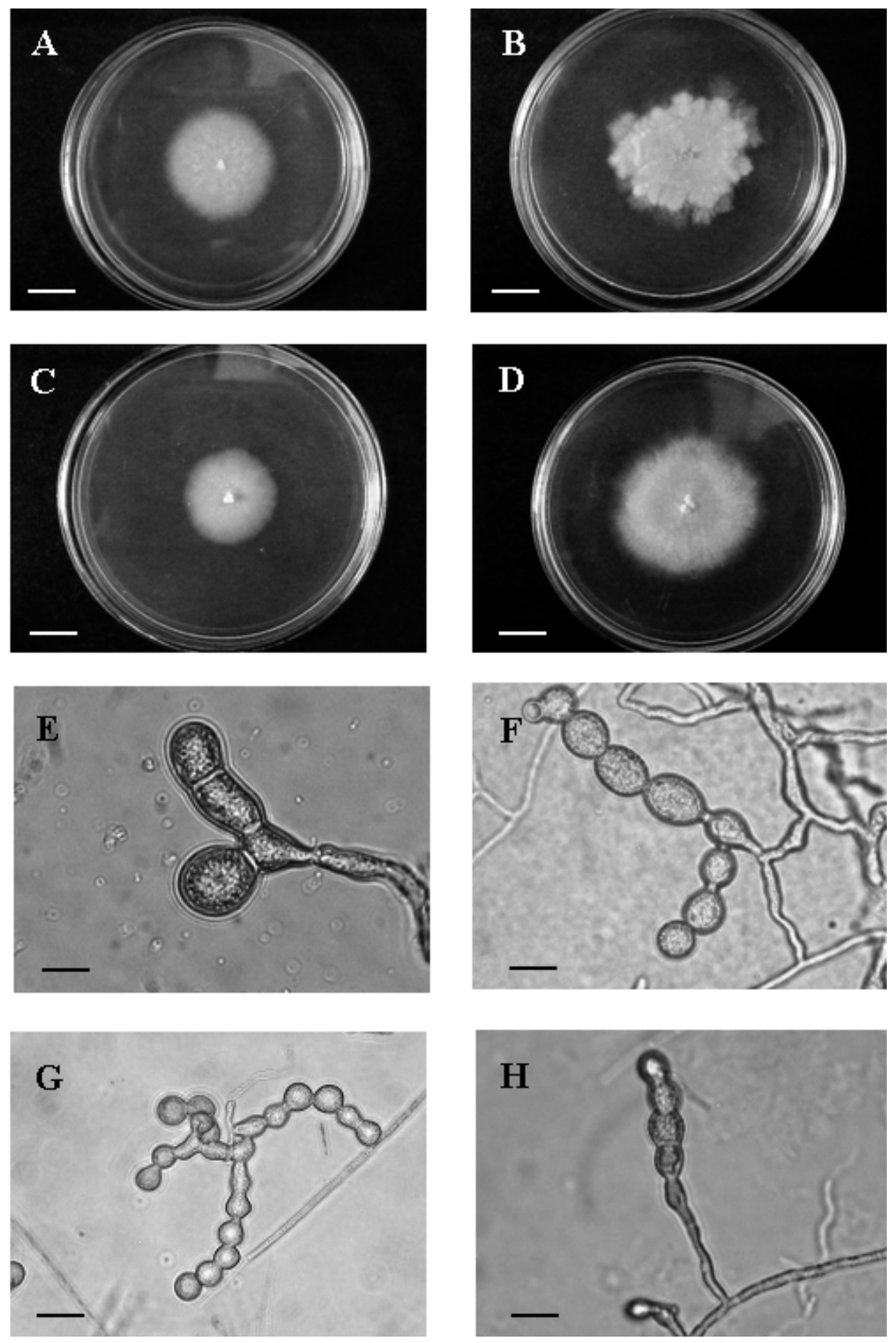

Figure 1. Any isolates of plants of Laeliinae. A. Isolate of Acianthera hamosa. B. Cattleya elongata. C. Brassavola tuberculata. D. Dimerandra emarginata. Scale bar is $1 \mathrm{~cm}$. Any monilioid cells of other isolates. E. Isolate of Sophronitis flavasulina. F. Sophronitis pabstii. Scale bar is 3 ?m, G. Epidendrum orchidiflorum and H. Cattleya tenuis. Scale bar 5 ?m. 


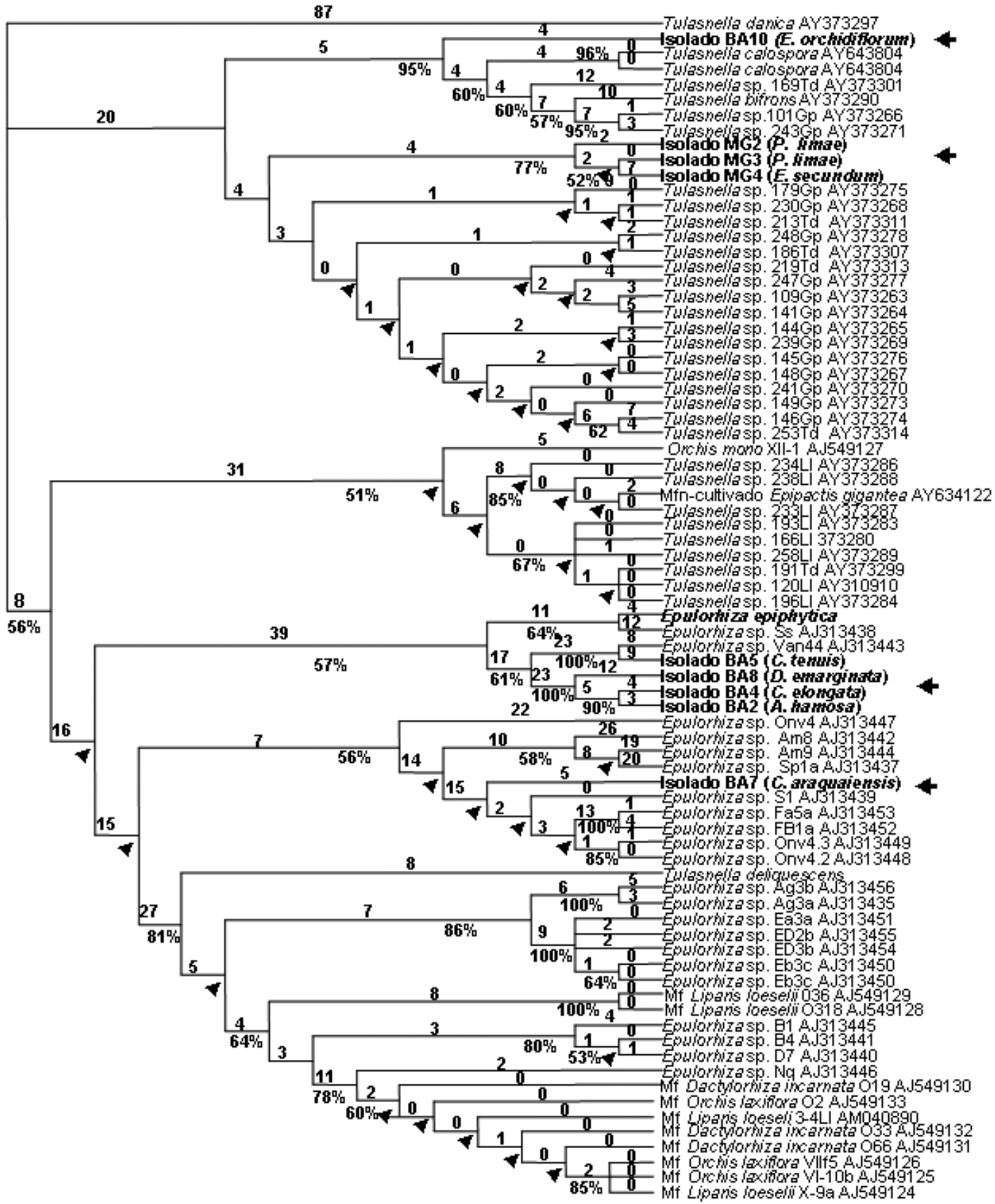

FIGURE 2. Fungal internal transcribed spacer phylogeny suggesting that the isolates of Laeliinae form mycorrhizal associations with fungi of the genus Tulasnella. The arrows show where the isolates of Laeliinae are. 
Currently these studies have been decreasing, which reflects, for instance, the insignificant number of anamorphic fungi of described Epulorhiza species (Currah and Zelmer, 1992, Zelmer and Currah, 1995, Currah et al. 1997a, Pereira et al. 2003), as well as the high number of sequences deposited in GenBank without any definition in the specific level (McCormick et al. 2004, Shefferson et al. 2005).

It is not known if this putative preference could be extended to all genera inside Laeliinae. Some studies has already pointed out this possible preferential relationship in the mycorrhizal association in some few species of Laeliinae (Curtis, 1939, Nogueira et al. 2005, Pereira et al. 2001, 2003, Zettler et al. 1999). Future investigations will be carried out in order to verify the pattern of mycorrhizal association in Laeliinae genera for the development of a future program of symbiotic propagation of threatened Brazilian species.

ACKNOWLEDGMENTS. I would like to thank all the logistics from the Research Lab in Microbiology (LAPEM), coordinated by Prof. Dr. Aristóteles Góes-Neto and from the Plant Molecular Systematics Lab (LAMOL), coordinated by Prof. Dr. Cássio van den Berg. I would also like to thank CNPq, FAPESB and the Mycorrhizal association Lab (Federal University of Viçosa, Minas Gerais, Brazil) by giving me a clone of E. epiphytica to be included in the phylogenetic analysis.

\section{LITERATURE CITED}

Almeida, P.R.M.de 2006. Associação micorrízica na subtribo Laeliinae (Orchidaceae). Monograph. State University de Feira de Santana, $56 \mathrm{p}$.

Andersen, T.F. 1990. A study of hyfal morphology in the form genus Rhizoctonia. Mycotaxon 37: 25-46.

Britto, I.C., L.P. Queiroz, M.L.S. Guedes, N.C. Oliveira \& L.B. Silva. 1993. Flora Fanerogâmica das dunas e lagoas do Abaeté, Salvador, Bahia. Sitientibus 11: 3146.

Cruz, D.T. da, E.L. Borba \& C. van Den Berg. 2003. O gênero Cattleya Lindl. (Orchidaceae) no estado da Bahia, Brasil. Stientibus 3 (1/2): 26-34.

Currah, R.S. \& C.D.A. Zelmer. 1992. Key and Notes for the Genera of Fungi with Orchids and a new Species in the Genus Epulorhiza. Rep. Tottori Mycol. Inst. 30: 4359.

Currah, R.S., L.W. Zettler \& T.M. McInnis. 1997a. Epulorhiza inquilina sp. nov. from Platanthera
(Orchidaceae) and a Key to Epulorhiza Species. Mycotaxon 61: 338-342.

Currah, R.S., C.D. Zelmer, S. Hambleton, \& K.A. Richardson. 1997b. Fungi from orchid mycorrhizas. In: Arditti, J. \& Pridgeon, A. M. Orchid Biology. Kluwer Academic Publishers. Dordrecht/Boston/London, 1997, 117-170.

Curtis, J.T. 1939. The relation of specificity of orchid mycorrhizal fungi to the problem of symbiosis. Am. J. Bot. 26: 390-398.

Doyle, J.J. \& J.L. Doyle. 1987. A rapid isolation procedure for small quantities of fresh tissue. Phytochemical Bulletin, 19: 11-15.

Dressler, R.L. 1993. Phylogeny and classification of the orchid family. Dioscorides Press, Portland.

França, F., E. Mello \& C.C. Santos. 1997. Flora de Inselbergs da região de Milagres, Bahia, Brasil: I. Caracterização da vegetação e lista de espécies de dois Inselbergs. Sitientibus 17: 163-184.

Felsenstein, J. 1985. Confidence limits on phylogenies: an approach using the bootstrap. Evol. 39: 783-91.

McCormick, M.K., D.F. Whigham \& J. O’Neill. 2004. Mycorrhizal diversity in photosynthetic terrestrial orchids. New Phytol. 163: 425-438.

Nogueira, R.E., O.L. Pereira, C.M. Kasuya, M.C. Lanna da S. \& M.P. Mendonça. 2005. Fungos micorrízicos associados a orquídeas em campos rupestres na região do Quadrilátero Ferrífero, MG, Brasil. Acta Bot. Bras. v.19, 3: 417-424.

Otero, J.T., J.D. Ackerman \& P. Bayman. 2002. Diversity and Host Specificity of Endophytic Rhizoctonia - like Fungi from Tropical Orchids. Am. J. Bot. v. 89, 11: 1852-1858.

Otero, J.T., J.D. Ackerman \& P. Bayman. 2004. Differences in mycorrhizal preferences between two tropical orchids. Mol. Ecol. 13: 2393-2404.

Pereira, L.O. 2001. Caracterização morfológica e molecular de fungos micorrízicos de sete espécies de orquídeas neotropicais. $47 \mathrm{pg}$. Dissertação (Mestrado em Microbiologia do Solo), Universidade Federal de Viçosa, UFV, Minas Gerais.

Pereira, L.O., C.L. Rollemberg, A.C. Borges, K. Matsouka \& M.C.M. Kasuya. 2003. Epulorhiza epiphytica sp. nov. isolada from mycorrhizal roots of epiphytic orchids in Brazil. Mycoscience, 44: 153-155.

Rasmussen, H.H. 1995. Terrestrial Orchids from seed to Mycotrophic plant. Cambridge University Press.

Swofford, D.L. 1998. PAUP: Phylogenetic analysis using parsimony and other methods, version $4.0 \mathrm{~b} 6$.

Sunderland: Sinquer.

Shefferson, R.P., M. Weib, T. Kull \& L. Taylor. 2005. High specificity generally characterizes mycorrhizal association in rare Lady's Slipper orchids, genus Cypripedium. Mol. Ecol. 14: 613-626. 
Sneh, B., L. Burpee, A. Ogoshi. 1991. Identification of Rhizoctonia species. APS Press, The American Phytopathological Society, St. Paul, Minnesota, USA.

Taylor D.L., T.D. Bruns. 1997. Independent, specialized invasions of ectomycorrhizal mutualism by two nonphotosynthetic orchids. Proc. Nat. Acad. Sci. USA 94: 4510-4515.

Taylor, D.L. \& T.D. Bruns. 1999. Population, habitat and genetic correlates of mycorrhizal specialization in the 'cheating' orchids Corallorhiza maculata and $C$. mertensiana. Mol. Ecol. 8: 1719 - 1732.

Taylor, D.L., T.D. Bruns, J.R. Leake \& D.J. Read. 2002. Mycorrhizal specificity and function in mycoheterotrophic plants. In: van der Heijden, M. C. A., Sanders I, eds. Mycorrhizal Ecology. Berlin, Germany: Springer Verlag, p. 375-413.

Thompson, J.D., T.J. Gibson, F. Plewniak, F. Jeanmougin \& D.G. Higgins. 1997. The clustral - Windows interface: flexible strategies for multiple sequence alingnment aided by quality analysis tool. Nucl. Acids Res. 24: 4876-4882.

Wacurp, J. H. \& P.H.B. Talbot. 1967. Perfect states of rhizoctonias associated with orchids. New Phytol. 66: 631-641.
Wacurp, J.H. \& P.H.B. Talbot. 1971. Perfect states of rhizoctonias associated with orchids - II. New Phytol. 70: 35-40.

Wacurp, J.H. 1981. The mycorrhizal relationship of Australian orchids. New Phytol. 87: 371-381.

Wacurp, J.H. 1988. Mycorrhizal associations of isolates of Sebacina vermifera. New Phytol. 110: 227-231.

Withner, C.L. 2000. The Cattleyas and their relatives. Vol. VI. The South American Encyclia Species. Timber Press, Portland, $153 \mathrm{p}$.

White, T.J., T.D. Bruns, S. Lee \& J.W. Taylor. 1990. Amplification and direct sequencing of fungal ribosomal RNA genes for phylogenetics. Pp. 315-322 in: G. Maidh, J.J. Sninsky \& T.J. White (eds.), PCR Protocols: A guide to methods and applications. New York: Academic Press.

Zelmer, C.D. \& R.S. Currah. 1995. Ceratorhiza pernacatena and Epulorhiza caledulina spp. nov.: mycorrhizal fungi of terrestrial orchids. Can. J. Bot. 73: 1981-1985.

Zettler, L.W., Burkhead, J.C., Marshall, J.A. 1999. Use of a mycorrhizal fungus from Epidendrum conopseum to germinate seed of Encyclia tampesis in vitro. Lindleyana 14: 102-105.

Paulo Ricardo Almeida is CNPq Scholarship/ graduate student - Msc. student in Botany from State University of Feira de Santana. The first work was developed during the undergraduation course focusing on the mycorrhizal association in subtribe Laeliinae. These work culminated in the Bachelor's monograph, "Mycorrhizal association in subtribe Laeliinae (Orchidaceae)". Currently, he is working with populations of two species of Encyclia from distinct environments that occur in the state of Bahia, Brazil. The following questions are being addressed in this study: (i) if there is a putative preference in this association and (ii) if both plant species have distinct symbionts, and aiming to an efficient in situ and ex situ conservation of these plants.

Cassio van den Berg is graduated in Agriculture at Universidade de SãoPaulo, Brazil, has a master degree in Ecology at Universidade Estadual de Campinas, Brazil, and a PhD in Botany from the Royal Botanical Gardens, Kew and University of Reading, UK. Currently he is full professor at Universidade Estadual de Feira de Santana, Brazil, with research focus on orchid systematics, plant molecular systematics and plant population genetics.

Aristóteles Góes-Neto is graduated in B.Sc. in Biology, Federal University of Bahia (UFBA), Brazil (1994) and Ph.D. in Botany, Federal University of Rio Grande do Sul (UFRGS), Brazil (2001). Currently, he is titular professor of the Dept. of Biology, State University of Feira de Santana (UEFS), Brazil, coordinator of Research Laboratory in Microbiology (LAPEM), and coordinator of Graduate Program in Biotechnology (M.Sc. and Ph.D. levels) at the same University. He is also member of the Scientific and Technical Chamber of Biological Sciences and Environment of the Science Foundation of the State of Bahia, Brazil (FAPESB). His research lines include Diversity and Evolution, Genomics/Proteomics, and Biotechnology of Fungi with emphasis on Basidiomycota. 